\title{
Historiography of the Old Belief and Researchers Coming from the Old Believers in the Baikal Region
}

\author{
Nikolay V. Abaev a and Oleg V. Zhuk ${ }^{\mathrm{b} *}$ \\ ${ }^{a}$ Tuvan State University \\ 36 Lenin Str., Kyzyl, Republic Tuva, 667000, Russia \\ ${ }^{b}$ Institute for Mongolian, \\ Buddhist and Tibetan Studies SB RAS \\ 6 Sakhyanovoi, Ulan-Ude, 670047, Russia
}

Received 05.04.2018, received in revised form 01.08.2018, accepted 14.08.2018

The article analyzes the historiography of the study of the Old Belief and examines the problems of its interpretation, formed under the influence of various ideological concepts and methodological approaches to this problem. The object of research of this work is the formation of various positions of historians in connection with the temporal and social aberration, the attitude of the state, the church to the phenomenon of the Old Belief, and also the process of forming its own historiography.

The subject of the study is the patterns of the evolution of historiography on this issue and the formation of the Old Believers' own historiographical concept.

Keywords: The Semey, Old Believers, Russian Orthodox Church, religion and state.

Research area: culturology.

Citation: Abaev, N.V., Zhuk, O.V. (2018). Historiography of the Old Belief and researchers coming from the Old Believers in the Baikal region. J. Sib. Fed. Univ. Humanit. soc. sci., 11(8), 1174-1187. DOI: 10.17516/1997-1370-0300.

To date, the main task of historical science is to recreate the objective reality in connection with the sociocultural transformations of the last decades that have changed the vector of humanitarian research. The breakdown of traditional and Soviet modernist ideological concepts with the transition to a new depersonalized democratic society poses a number of problems for our society. Among these problems, we highlight the issues of achieving social harmony through legal regulation in the polyconfessional society of the relationship between religious institutions and the existence of an adequate state-legal religious policy.

(C) Siberian Federal University. All rights reserved

* Corresponding author E-mail address: hom17@mail.ru 
These factors cannot but affect the study of the Old Belief as one of the most complex phenomena in Russian religious culture.

At present, in Russia, state policy is concerned with the notion of "spiritual security" more than ever; in other words, it means the reliable protection of spiritual values and legal norms of citizens of the Russian Federation. To a large extent, this concept gives rise to concern over the activities of confessional entities that are nontraditional for Russia. To date, these new formations are beginning to claim a dominant position in the transboundary Baikal region. The urgency of this problem lies in the fact that transboundary regions are isolated from traditional religious centers and heteroconfessionality is inherent in them. Today, there is an increase in the role of the religious factor in political and everyday life.

Pre-revolutionary official historical science extremely negatively assessed the schismatic movements, calling them "heresy", because it saw a danger to the state system in them. Three directions can be distinguished in pre-revolutionary historiography: church historiography, Old Belief historiography and secular historiography. Secular historiography, in turn, is divided into official and unofficial historiography.

The book "Church Historiography of the Old Believers: Emergence and Evolution (Second Half of the $17^{\text {th }}-$ Early $20^{\text {th }}$ Centuries)" by K.A. Kuzoro (Kuzoro, 2011) was written based on the religious historiography of the $17^{\text {th }}-20^{\text {th }}$ centuries. The book clarifies that the researcher obtained mainly the work of the Old Believers and secular historians, while church history remained a less examined topic for the study. The author did his research on the confrontation and polemics of Old Belief historiography and religious historiography, which is represented by the Russian Orthodox Church.

"A search for the schismatic Brynsk faith" (Rozysk o raskol'nicheskoi..., 1885) can be singled out as one of the most vivid publications of religious pre-revolutionary historiography. The author of this work defined his attitude to the schism in this way, "The demonic birds, schismatics, who flew from their Brynsk nest, taught many people to run away from the Holy Church ... Deceiving and seducing simple peasants and women, they said, the church is not a church, and priests are not priests any longer" (Blagodatnyi ogon'...).

The official position has not changed in the prism of the centuries. But still, the Old Believers are dearer to the Russian Orthodox Church than other religious denominations, today they believe that this branch is without a root, "A living tree should bear fruit. Since the Church's purpose is to lead its children to salvation, only 
the spiritual gifts that members of the church community acquired should be estimated. The mass of saints is the fruit of the Church" (Orthodoxy). In turn, "the Old Believers saw themselves as continuers of ancient Christianity, unlike the Russian Orthodox Church, which was focused only on preserving continuity, transferring institutional power" (Humphrey, 2014).

It can be noted that there were also psychological reasons for the schism with the reformation of the ritual that were affected not only by social factors. The followers of the classical Freudian approach viewed the ritual primarily as a complex defense mechanism of people with unstable psyche who see protection in a ritualization, "The obsessive neurotics are pursued by the possibility of realizing harmful and destructive desires, the whole of the obsession neurosis is built up as a protection against it. They defend themselves from such a threat by taking a definite position with the help of extremely complicated rituals, sometimes linked to the most strange superstitions" (Freud, 2002).

Many believers thought that in fact a new faith was introduced in Russia to replace the old one. Protests began against the innovations of Nikon. The supporters of old rituals ingulfed the Tsar by the petitions, in which the "new unknown faith" was condemned as a heresy, "its teachings are soul-worthy, its services are not services, sacraments are not sacraments, pastors are wolves" (Bolonev, 1992) At the Moscow Assembly in 1681-1682 bishops asked the Tsar to help in the fight against the schism, and the ominous fires of the Inquisition soon began to blaze. The famous law "12 articles of Tsarevna Sophia" (Zakon Moskovskogo gosudarstva..., 1836) came out, which instructed to burn the Old Believers in the wood and scatter their ashes in the wind after triple interrogation (Zakon Moskovskogo gosudarstva..., 1836), if they did not want to switch to new rituals (Nikolaev, 2016).

The current situation for the initial period can be characterized by a quotation from the Holy Scripture, the chapter of the Revelation 15:2, "And I saw as it were a glass sea mixed with fire; and the song of Moses, the servant of God, and the song of the Lamb defeated the beast, the image of it, the mark thereof, and the number of its name, stand on this sea of glass, holding the harp of God, howling and saying: Great and marvelous are thy works." At that time, the Old Believers believed that the end of the world had come and the kingdom of the "Antichrist", the antipode of Christ, came into being in the person of the transformers of the church reform, while punitive activities against the Old Believers strengthened their belief that the eschatological end of time had come. 
The second significant work in church historiography was the book "The History of the Russian Schism" (Makarii (Bulgakov), 1889); compared with the works of the $17^{\text {th }}$ century, it was written not to betray the curse, but to return the Old Believers to the bosom of the institutional mother church. As for the passion for rituals, which were performed by the Old Believers, the criticism of their ideological opponents boiled down to the following, "We are Russians and should acknowledge ourselves obligated to be in accord with the Greeks regarding worship; Consequently, we must have had the division into three parts in the same way as Nikon did, instead of the adopted (on the groundless reasons mentioned above) unified use of schismting" (Golubinsky, 1892a). E.E. Golubinsky was a secular historian, but his position was similar to the position of the Russian Orthodox Church because of the ideological influence and position of the state, which saw the support of the autocratic system in the church. E.E. Golubinsky considered the position of the Old Believers incorrect and called for reunification with the church and forgetting about the schism (Golubinsky, 1892b). He is a historian of prerevolutionary official historiography. Evgeny E. Golubinsky, a historian of the Russian Church and church architecture, an ordinary academician of the Imperial Academy of Sciences from the department of Russian language and literature, the author of a number of fundamental studies on the history of the Russian Church, is considered a supporter of positivism. Despite the fact that he was a supporter of positivism, he regarded the schism from the position of the Russian Orthodox Church and actively polemicized with the Old Believers. In the modern historiography S.A. Zen'kovsky likewise negatively speaks about the church schism and the Old Believers (1995). Probably, this is a tradition of the pre-revolutionary school.

One can note the negative attitude to the Old Believers not only in pre-revolutionary historical works, but also in statistical data, for example, in the "Atlas of Asian Russia" (Aziatskaia Rossiia, 1914), where the negative context is given to the movement of the schismatics, "The wild fanaticism of the schismatics did not spare the Orthodox laity. In 1686 in Kamensk-Tyumensk the Pokrovskaya church burnt down together with 250 parishioners because of the arson of the schismatics (Aziatskaia Rossiia, 1914: 204) [The quotation is translated into the modern post-reform language]. However, the positive description of the Old Believer population in Siberia was also preserved, "... The Semey - not only the type, but also the custom and, in general, the entire Russian life order remained completely inviolable in this group of settlers. In the southern Altai, there are up to 30 thousand Old Believers, nicknamed Poles, who do not mix, are beautiful, slender, especially women. The hair is light or fair-haired, the 
forehead is wide and straight, the eyes are large, the nose is regular and the facial features are generally regular. They are sociable, cheerful, like adornments, women wear sarafans; the well-to-do people, however, Siberians are generally richer than Russian peasants" (Aziatskaia Rossiia, 1914: 186) [The quotation is translated into the modern post-reform language].

This statistical collection nevertheless regards the Old Belief as an integral part of the socio-political and economic history of Siberia and criticizes schismatics less than in other official works written during this period. But do not forget that not all prerevolutionary historiography negatively treated the schism. Only the statesmen and supporters of the traditionally conservative trend in historiography did. The authors of these works set themselves the task of ideological strengthening of state power. That is why the conceptual positions of this group are far from scientific research.

In the 60 's -70 's of the $19^{\text {th }}$ century there was a discussion ensued between representatives of the clerical-conservative and democratic concepts of the schism over the appearance of A. Shchapov's book "The Russian Schism of the Old Belief". The historian has proved that the root causes of the schism lie in the social, economic and spiritual-moral state of the people, linked the development of regional centers of the Old Belief and zemstvo-regional theory, introduced the works of Siberian Old Believers into scientific circulation. The ideas of A.P. Shchapov were most developed in the work of V.V. Andreev (1904). Some historians of the clerical direction (I. Nil'sky, P. Mel'nikov, N.F. Kapterev) agreed with the fact that the schism appeared as "a consequence of the shortcomings of Russian life" (Mel'nikov, 1864).

Consequently, the emergence of liberal currents and the growing instability caused the emergence of various points of view of the church schism in Russian society. But the development of social thought was stopped because of the revolution of 1917, which dared to destroy church ideology, establishing an entirely new world outlook and attitude.

Modern historiography and historiography of the Soviet period is less negative towards the era of schism. The Soviet historiographic school is characterized by a description of the phenomenon of the Old Belief as an attempt of the masses to fight for their rights.

During the Soviet era, the study of the Old Belief was not an important direction in history, which is confirmed by the insignificant number of works on this subject. Humanitarian research in the Soviet era was under a heavy oppression of ideology. As a whole, they depended on the course of the party in relation to religion. Falling into 
the category of atheistic literature, they contained an athereligious discourse and were closed to a wide range of readers.

Despite this, there were people who were interested in their own history and origin. F.F. Bolonev is a representative of the Soviet school of historians and accordingly in his works he gives an interpretation of the development of events from the point of view of the movement of masses. This is characteristic of Soviet historiography in general. In the works of F.F. Bolonev we can trace the negative narrative to the reforms of Peter I and a negative evaluation of the increase in serfdom.

Modern interpretations have a more pronounced personal character. For example, a local historian, an Old Believer, S.P. Petrov thought that "the church reform of the $17^{\text {th }}$ century, conducted by Tsar Aleksey Mikhailovich the Quietest and the schismatic patriarch Nikon, led the Russian people to fratricide. The Quietest Tsar and the schismatic patriarch Nikon created a new church, which was popularly called 'The Nikonian Church'. Using the power, they called it the Orthodox Church, although in the church they founded, the Orthodox foundations were replaced by Catholicism and Protestant teachings, and eventually the Nikonian Church departed almost completely from the Orthodox faith. Under Peter I, in addition, it became synodal, becoming a ministry of ideology, headed by the Chief Procurator of the Synod, because the royal decree abolished the patriarchate. The followers of the old Orthodox faith and even the majority of the Old Believer population in the first years after the schism remained faithful to the old paternal piety, continued to preserve the Orthodoxy of Holy Russia. The drained and devastated Russian Church before the schism remained with the people who preserved it, despite the great and cruel reprisals against the old religion, perpetrated by the Nikonians" (Petrov, 2013).

We should note that the attitude of Peter I, S.P. Petrov and F.F. Bolonev to the reforms is generally the same, however, F.F. Bolonev saw the popular force against an alien corrupting influence in the movement of the Old Believers. This is indicated in his work "The Semey" (Bolonev, 1985). Relying on the works of N.I. Kostomarov and N.I. Nikol'sky, he describes the Old Believers only from the positive side, justifying self-immolation (Bolonev, 1985: 10).

"Self-immolation is an extreme measure of protest against injustice, it is a provocation of a cornered person. It cannot be explained just by fanaticism, as official propaganda did, and this view is tenacious to the present day. N.I. Kostomarov writes, 'Schismatic self-immolations were exploits that were as much heroic as the determination of the fatherland defenders would be today: it is better to perish in a 
fortress, blowing it into the air, than surrender to the enemy"' (Bolonev, 1985: 11). The Soviet influence in this work is also noticeable, as the works of K. Marx and V.I. Lenin are used.

Most of F.F. Bolonev's works are written on the topic of the Old Belief: Russian Orthodox Posts, "Old Believers of Siberia: Culture and Ways of Life Support", "Old Believers of Transbaikalia: Traditional Culture and Modernity (concerning the problem of extinction of the Old Belief). Labor and moral education of the Old Believers of Transbaikalia in the post-reform period" (Bolonev, 1995).

Firs F. Bolonev comes from an Old Believer family, was born in the village of Kunalei. His works are distinguished by high morality and love for people, to their native land. This can be traced in his works devoted to a simple people who managed to survive and preserve their culture and enrich the culture of the autochthonous population. F.F. Bolonev emphasizes that the Old Believers taught the indigenous population to farm, while the local tribes of the Buryats-Mongols taught the Old Believers to survive in the hardest conditions. He noted mixed marriages, paid attention to the mutual enrichment of cultures not only from the Buryat side. Besides, he emphasized the fact that the Old Believers absorbed elements of Polish and Ukrainian culture.

Of interest are the works of Vasily M. Pykin, PhD in History, born in the family of the Old Believers, namely the popovets Pykins and Chistiakovs. In particular, he wrote a book "V.P. Girchenko's contribution to the study of the history of Transbaikal Semey Old Believers $\left(17^{\text {th }}-18^{\text {th }}\right.$ centuries)" (Mykin, 2009). We managed to consider the first version, released in 2001, "F.F. Bolonev, V.M. Pykin. Farmers and warriors of the Tarbagatai and Kuitun volosts of the Transbaikal region at the beginning of the $20^{\text {th }}$ century." The covers are almost identical, but in the text of the new version the material was cut out slightly, and the name was changed, which did not affect the quality of this book. Pykin is a good historian archivist, who did a great job in the archive. However, in his works, the influence of the interpretation of the events of F.F. Bolonev is noticeable. In general, Old Believer historiography always describes the Old Believers, the phenomenon of schism is considered only from the positive side. In order to see the full picture, it is necessary to consider other points of view on this topic.

It is also possible to classify the listed researchers as Old Believer historiographers. In spite of the fact that these historians are mainly followers of the Soviet school, ethnocentric discourse can be traced in their works. In these works the Old Believers and their relationship with the surrounding reality are put in the center of the world. 
The very formulation of the religious definition of the historiography of the Old Believers seems to us rather difficult, in view of a certain internal contradiction that is revealed when trying to define the term. To date, there are various definitions, where, for example, the Old Belief is close to sectarian and heretical movements. In a modern poly-confessional society, the definition of the term must be capacious and contain the applicability to various Old Believer movements and "doctrines." On all these grounds, the definition of the term of Old Belief is expressed by M.O. Shakhov. He points out in his works that the Old Believers call themselves Old Orthodox or Orthodox Christians. This is indicated in his doctoral work. "Old Believer World View, religious and philosophical foundations and attitudes towards society" (Shakhov, 2000).

Among modern researchers studying the Old Belief, who do not have a strong involvement and interest, we can name such researchers as S.V. Vasil'eva, the author of such articles as "The Old Believer clergy of Transbaikalia and Harbin" (Vasil'eva, 2002a), "Historical sources on the religious freedom of the Old Believers of Transbaikalia at the beginning of the $20^{\text {th }}$ century" (Vasil'eva, 2002b) "The general and the special in the Old Belief of Belarus and Transbaikalia" (Vasil'eva, 2003), "Economic ethics of the Old Believers of Transbaikalia as a feature of regional entrepreneurship" (Vasil'eva, 2004), as well as more than 47 articles and monographs. The Old Believer population, in her estimation, is strong-willed people, who managed to survive in harsh climatic conditions due to their faith and mutual assistance. In her works she relies only on archival and historical data.

Foreign historiography on the subject, for example, the work of Carolina Humphrey "Schism, Event, and Revolution: The Old Believers of Trans-Baikalia Schism, Event, and Revolution: The Old Believers of Trans-Baikalia" (Humphrey, 2014), which describes the influence of the revolution on traditional life, as well as analyzes why the Old Believers in the first ranks joined the anti-government armed movement. It is the internal protest against oppression that was the reason why the Old Believers treated new government extremely positively. This could not help affecting the transformation of the traditional way of life of the Old Believers, since the revolutionary idea contained modernist principles.

As for the foreign historiography, the book of the French scientist Pierre Pascal "Protopop Avvakum and the beginning of the Schism" (Pascal, 2011) stands out there. Due to this work, he became Doctor of Slavic studies with the highest distinction at the French University of Sorbonne. 
The Old Belief draws the attention of scientists of various directions due to its multifacetedness, a huge influence on spiritual culture and the formation of mentality. In the historiography science the term of the Old Belief is firmly entrenched. The problem of the state and the Old Belief is viewed through the prism of relations between them and state structures. That is how the forming of a government position in relation to the Old Believers is analyzed, the activities of institutional powers and ideological concepts are systemized and studied.

It can be noted that the works of the pre-revolutionary period of historiography are more popular in nature, while the post-revolutionary period differs by the scientific component.

Having examined the different types of historiography of the "The Semey" history, we can come to the conclusion that the Old Believers in their works exaggerate the role of the schism for Russia and negatively look at the modernization processes carried out by the imperial government. The Old Belief in Petrov's works is true faith, while in the opinion of F.F. Bolonev, this is a protest against the oppression of the people by the tsarist government. Differences in interpretation lie in the fact that the researchers, despite the fact that they have a common ethnic origin, differ in the degree of engagement. F.F. Bolonev was more susceptible to the influence of the Soviet historiographic school, while S.P. Petrov focuses on the religious component. Based on the examined problem, it can be said that these researchers, probably, due to their ethnopsychological characteristics, either wished to become an exponent of ethnonational interests or needed to relate themselves to a community having their own root and to study or join the traditions of their ancestors. It should be understood that a high adequate self-esteem is the natural state of the vast majority of ethnic groups and their representatives. Besides, for a long period of time, the state and the Russian Orthodox Church treated the Old Believers schism extremely negatively. The state for some time saw a danger to the state system in them ... It is because of the strong outside pressure why the Old Believer culture remained conserved in its diversity.

The phenomenon of how the Old Believers became patriots of the socialist system having the anti-state mood against the imperial power before is also interesting. F.F. Bolonev extremely positively described the Soviet and socialist period of the development of the Old Believers' culture, which had already begun to turn into an ethnographic component in addition to the single Soviet people. The Old Believers themselves positively assessed the transformations of the revolution and the new Soviet authorities in opposition to autocratic power. We see a possible answer in the fact that 
it is most likely the involvement of many nationalities in the state building of a single state and the existence of a common ideology and purpose.

In the era of modernity and postmodernity there was only an ethnographic moment left from the Old Believer culture, despite the fact that there is practically no religious persecution in Russia today. According to eyewitnesses, during Soviet times more ethnic and ethnographic features were preserved than now. This is primarily due to the inclusion of Russia in the global market, as well as the development of capitalist relations. The old forms of traditional belief and management that existed in the Soviet Union, when confronted with the market, were virtually destroyed. Only scattered religious groups and an ethnographic component preserved through commercialization remained there.

That is why it was important to trace the transformation of views on this issue. Domestic and foreign historiography has done a great deal on this issue, showing all the changes in the discourse in relation to the movement of the Old Believers, reflecting the temporary and social aberration. Since its inception, it has not been homogeneous, including representatives and bearers of various concepts and ideas in the pre-revolutionary period.

\section{References}

Afanasii Gumerov, nasel'nik Sretenskogo monastyria. V chem zakliuchaiutsia razlichiia mezhdu pravoslaviem i staroobriadchestvom [Athanasius Gumerov, a resident of the Sretensky Monastery. What are the differences between Orthodoxy and Old Believers?]. In Web-site Pravoslavie.Ru. [Portal Pravoslavie.Ru.]. Available at: http://www.pravoslavie.ru/6485.html (Accessed February 11, 2018).

Andreev, V.V. (1904). Raskol i ego znachenie vnarodnoi russkoi istorii. Istoricheskii ocherk [Schism and its significance in folk Russian history. Historical sketch]. St. Petersburg.

Aziatskaia Rossiia [Asian Russia] (1914), 1. Izd. Pereselencheskogo upravleniia, glavnogo upravleniia zemledel'chestva. St. Petersburg.

Bibliia knigi sviatogo pisaniia novogo $i$ starogo zaveta [The Bible of the book of the Holy Scripture of the New and Old Testament] (2016). Russian Biblical community, 1290.

Blagodatnyi ogon'. Pravoslavnyi zhurnal [Holy Fire. Orthodox magazine]. Available at: www.blagogon.ru/articles/207/ (Accessed April 9, 2018).

Bolonev, F. (1985). Semeiskie Istoriko-etnograficheskie ocherki [The Semey historical and ethnographic essays]. Izd. Buryatia, Ulan-Ude. 
Bolonev, F.F. (1992). Semeiskie: Istoriko-etnograficheskie ocherki [The Semey: Historical and ethnographic essays]. Ulan-Ude, Buryat Publishing House, 224 (8).

Bolonev, F.F. (1995). Staroobriadtsy Zabaikal'ia: traditsionnaia kul'tura i sovremennost' ( $\mathrm{k}$ probleme ugasaniia staroobriadchestva) [Old Believers of Transbaikalia: traditional culture and modernity (concerning the problem of extinction of the Old Believers)], In Aborigeny Sibiri: probl. izuch. ischezaiushchikh iazykov $i$ kul'tur: Tez. dokl. mezhdunar. nauch. konf [Aborigines of Siberia: problems of the study of disappearing languages and cultures: Proceedings of the reports of International Research-to-Practice Conference], 2 (Arkheologiia i etnografiia [Archeology and Ethnography]). Novosibirsk, 88-90.

Freud, Z. (2002). Naviazchivye deistviia i religioznye obriady [Obsessive actions and religious rites], In Issledovaniia po psikhoanalizu kul'tury [Research on psychoanalysis of culture]. St. Petersburg, Aleteiia, 562 p.

Golubinsky, E.E. (1892a). K nashei polemike so staroobriadtsami (Chastnye voprosy: O pesni alliluiia) [Concerning our polemics with the Old Believers (Particular questions: About the song of Hallelujah)], In Bogoslovskii vestnik [Theological Bulletin], 5, 197-223.

Golubinsky, E.E. (1892b). K nashei polemike so staroobriadtsami (Obshchie voprosy: Neobkhodimo li bylo Nikonovo ispravlenie obriadov i knig i v nastoiashchee vremia, ne nuzhdaetsya li sdelannoe Nikonom v kakikh-libo popravkakh?) [Concerning our polemics with the Old Believers (General questions: Was Nikonov's correcting rituals and books necessary and do Nikon's deeds need any corrections at present?)], In Bogoslovskii vestnik [Theological Bulletin], 1, 485-506.

Humphrey, C. (2014). Schism, Event, and Revolution: The Old Believers of TransBaikalia, In Current Anthropology, 55(S10). The Anthropology of Christianity: Unity, Diversity, New Directions, S216-S225. Published by: The University of Chicago Press on behalf of the Wenner-Gren Foundation for Anthropological Research Stable. Available at: www.jstor.org/stable/10.1086/678476 (Accessed 11-01-2018 02:25 UTC).

Kuzoro, K.A. (2011). Tserkovnaia istoriografiia staroobriadchestva: vozniknovenie $i$ evoliutsiia (vtoraia polovina XVII - nachalo XX v.) [Church historiography of the Old Believers: emergence and evolution (second half of the $17^{\text {th }}-$ early 20 th century)]. Tomsk state university, Tomsk State University Press, 180.

Makarii (Bulgakov), Metropolitan of Moscow (1889). Istoriia russkogo raskola, izvestnogo pod imenem staroobriadstva [The history of the Russian schism, known under the name of the Old Belief], In Sochineniia Makariia, mitropolita Moskovskogo. 
Izd 3-e [Writings of Makarii, Metropolitan of Moscow. The $3^{\text {rd }}$ Ed]. St. Petersburg: typolithography of R. Golike.

Mel'nikov, P. (1864). Istoricheskie ocherki popovshchiny [Historical essays of popovshchina]. Moscow.

Mykin, V.M. (2009). Vklad V.P. Girchenko v izuchenie istorii zabaikal'skikh staroobriadtsev - semeiskikh (XVII-XVIII vv.) [Contribution of V.P. Girchenko in the study of the history of Transbaikal Semey Old Believers $\left(17^{\text {th }}-18^{\text {th }}\right.$ centuries)], In Aktual'nye voprosy istorii Sibiri: Sed'mye nauch. chteniia pamyati prof. A.P. Borodavkina (Barnaul, 9-10 okt.) [Topical Issues of the history of Siberia: Seventh Scientific conference in memory of Professor A.P. Borodavkin (Barnaul, October 9-10). Barnaul, 24-26.

Nil'sky, I. (1864). Neskol'ko slov o russkom raskole (Po povodu broshiury: "Zemstvo i raskol" A. Shchapova) [A few words about the Russian schism. (Concerning the pamphlet "Zemstvo i raskol" by A. Shchapov)]. St. Petersburg.

Nikolaev, M.G. (2016). Tserkovno-obriadovye reformy Nikona [Church-ritual reforms Nikon], In Posviatim Voskresnyi den' Bogu! Staroobriadcheskie onlain-lektsii [Let's dedicate Sunday to God! Old Belief online lectures]. Available at: http://pvdb.ru/ (Accessed March 11, 2018).

Petrov, S.P. (2013). Staraia pravoslavnaia vera za Baikal-morem. Episkop Afanasii Tarbagataskii, Irkutsko-Amurskii i vsego Dal'nego Vostoka [The old Orthodox faith beyond the Baikal sea. Bishop Athanasius of Tarbagatay, Irkutsk-Amursk and the entire Far East]. Ulan-Ude, Community of Culture of the Semey of Republic of Buryatia.

Pascal, P. (2011). Protopop Avvakum inachalo Raskola [Avvakum and the beginning of the Schism]. Moscow, Znak.

Rostovskij D. (1855). Rozysk o raskol'nicheskoi brynskoi vere [A search Ifor the schismatic Bryn faith]. St. Petersburg., Aksion ehstin (2009). Available at: https:// azbyka.ru/otechnik/books/original/13779/13779-Розыск-о-раскольническойбрынской-вере.pdf

Shakhov, M.O. (2000). Staroobriadcheskoe mirovozzrenie, religiozno-filosofskie osnovy i otnoshenie $\mathrm{k}$ obshchestvu: religiozno-filosofskie osnovy i otnoshenie k obshchestvu. In Diss... d-ra filos. nauk: 09.00.06 [Old Believer world view, religious and philosophical foundations and attitudes towards society: religious and philosophical foundations and attitudes towards society. Doctoral dissertation]. Moscow, Russian Academy of Civil Service under the President of the Russian Federation, $377 \mathrm{p}$. 
Vasil'eva, S.V. (2002a). Staroobriadcheskoe dukhovenstvo Zabaikal'ia i Kharbina (problema kanonicheskogo obshcheniia) [The Old Believers clergy of Transbaikalia and Harbin (the problem of canonical communication)], In Vestn. Buriat. Un-ta. Ser. 4. Istoriia [Bulletin of Buryat State University. Series 4. History], 4. Ulan-Ude, Buryat State University Publishing House, 173-177.

Vasil'eva, S.V. (2002b). Istoricheskie istochniki o svobode veroispovedaniia staroobriadtsev Zabaikal'ia $\mathrm{v}$ nachale $\mathrm{XX}$ v. [Historical sources on the religious freedom of the Old Believers of Transbaikalia at the beginning of the $20^{\text {th }}$ century], In Vestn. Buriat. gosuniversiteta. Ser. 4. Istoriia [Bulletin of Buryat State University. Series 4. History], 5. Ulan-Ude, Buryat State University Publishing House, 162-169.

Vasil'eva, S.V. (2003). Obshchee i osobennoe v staroobriadchestve Belarusi i Zabaikal'ia [The general and the special in the Old Belief of Belarus and Transbaikalia], In Vestn. Buriat. un-ta. Ser. 4. Istoriia [Bulletin of Buryat State University. Series 4. History], 7. Ulan-Ude, Buryat State University Publishing House, 55-60.

Vasil'eva, S.V. (2004). Khoziaistvennaia etika staroobriadtsev Zabaikal'ia kak osobennost' regional'nogo predprinimatel'stva [Economic ethics of the Old Believers of Transbaikalia as a feature of regional entrepreneurship], In Vestn. Buriat. un-ta. Ser. 4. Istoriia $i$ vostokovedenie [Bulletin of Buryat State University. Series 4. History and Oriental Studies], 9. Ulan-Ude, Buryat State University Publishing House, 16-28.

Zakon Moskovskogo gosudarstva, izdannyj 7 aprelia st. st. (20 aprelia n. st.) 1685 g. [The Law of the Moscow State, published on April 7, 1685 old century (April 20, new century)] (1836), In Akty, sobrannye $v$ bibliotekakh i arkhivakh Rossiiskoi imperii Arkheograficheskoi ekspeditsiei imperatorskoi Akademii nauk (1645-1700) [Acts collected in the libraries and archives of the Russian Empire by the Archaeographic Expedition of the Imperial Academy of Sciences (1645-1700)], 4(284). St. Petersburg, 419-422.

Zen'kovsky, S.A. (1995). Russkoe staroobriadchestvo: dukhovnoe dvizhenie XVII veka [Russian Old Belief: Spiritual Movement of the $17^{\text {th }}$ Century]. Moscow, Tserkov'. 


\title{
Историография старообрядчества и исследователи - выходцы из старообрядческих семей \\ в Байкальском регионе
}

\author{
H.В. Абаев ${ }^{a}$, О.В. Жук \\ ${ }^{a}$ Тувинский государственный университет \\ Россия, 667000, Республика Тыва, Кызыл, ул. Ленина, 36 \\ ${ }^{6}$ Институт монголоведения буддологии \\ и тибетологии СО РАН \\ Россия, 670047, Улан-Удэ, ул. Сахьяновой, 6
}

В статье анализируется историография изучения старообрядчества и рассматриваются проблемы ее интерпретаций, сложивиихся под влиянием различных идеологических концепций и методологических подходов к данной проблеме. Объектом исследования данной работы является формирование различных позиций историков в связи с временной и сочииальной аберрацией, отношением государства, иеркви к феномену старообрядчества, а также процесс формирования собственной историографии.

Предметом исследования являются закономерности эволюции историографии по данной проблеме и формирование у старообрядиев собственной историографической конщепциии.

Ключевые слова: Семейские, старообрядиь, Русская православная ичерковь, религия и государство.

Научная специальность: 24.00.00 - культурология. 